\title{
The Effect of Repeated Reading Strategy in Teaching Reading Comprehension of Narrative Text at the Eight Grade Students of SMPN 36 Pekanbaru
}

\author{
Destina Kasriyati ${ }^{1)}$, Maharani $^{2)}$ \\ ${ }^{1)}$ Universitas Lancang Kuning \\ destina@unilak.ac.id \\ ${ }^{2)}$ Universitas Lancang Kuning \\ rani.maha690@yahoo.com
}

\begin{abstract}
Based on the result of observation that students got some difficulties to understand the content of reading comprehension, particularly main ideas, detail information, vocabulary, identify information, word reference and generic structure. The purpose of this research was to find whether the students who received in class experiment of repeated reading strategy had different skill in reading comprehension than students who did not receive treatment of the strategy at the second grade of SMPN 36 Pekanbaru. The design of this research was Experimental Research. This research was conducted on Jan 2018. The population of this research was the second grade of SMPN 36 Pekanbaru. The sample of this research were 2 classes as control and experiment class. Based on the test result, it was found that the average score of posttest was 85.33 and pre test was 71 . It means that the result of post test was getting higher than pretest. In conclusion, the use of repeated reading strategy could increase students reading comprehension in narrative text. There was different ability between experment and control class.
\end{abstract}

Keywords: Reading Comprehension, Narrative Text, Repeated Reading 


\section{INTRODUCTION}

Reading is one of receptive skills, which becomes an aspect that should be considered among language skills. In finding out the information of reading text, the reader should have good comprehension. A good reading comprehension will guide the reader to find out the meaning of the context, whether stated or not stated meaning. It is, a good comprehension is necessary to comprehend meaning what the writer writes.

Based on Standard of Competency and Basic Competency (SKKD) in KTSP curriculum, The Eight grade students are expected to be able to understand and respond meaningful written text in term of functional written text and simple short essay. In School-Based Curriculum (KTSP), reading is one of the skills that should be taught in learning English. State Junior High School 36 is one of the schools in Pekanbaru using Schoolbased Curriculum (KTSP) and minimal passing grade is 79 . The text types that should be learnt and taught in the eighth grade are descriptive text, recount and narrative text.

The problem in reading comprehension there are some faced by students in learning reading narrative text, especially in SMPN 36 Pekanbaru (Wednesday, Oct 25 $5^{\text {th }}$ 2017), The researcher found that the students could not understand about the content of reading text, The students could not identify the detailed information of the text, The students could not identify the main idea of the text, The students could not identify the generic structure of the text, The students could not identify word references and the students could not word meaning or vocabulary of the text. They difficulty also answer the questions given after reading a text.

. In generic structure, the students had difficulties to found orientation which tell about who, when and where of the event occurred That problem made the students felt difficult to answer well if the teacher gave question about narrative text to the students.

Based on situation above, English teacher had a big responsibility to made the students successful in their study. It needs their creativity to choose the best strategy that should be applied in teaching reading comprehension in order that the students could easily comprehend their lesson. Strategy was one thing that can determined the success of teaching learning process. And, in this research, the researcher used repeated reading strategy.

Regarding to the problem above, it need a solution for the solved the problem. It was namely repeated reading strategy. Repeated reading strategy Repeated Reading Strategy can be a good choice to be applied in 
classroom. Repeated Reading Strategy developing by Cox (2016) say this strategy is when a student reads the same text over and over again until the rate of readings has no errors. Moreover, it is especially helpful when students read a texts containing of new information. This is an effective strategy for the students to improve reading comprehension through discussing the problem in pairs. Students have a text that given by the teacher and they share their ideas with their pairs to find good answer of the text. After that, the researcher evaluates their answer through raise their hands to find out the correct answer from the students.

Siti (2012) conducted the research entiled "The effect of using Repeated Reading Strategy toward reading fluency at the second year students of SMPN 3 Kabun Rokan Hulu Regency in academic year 2012/2013" The sample of this research is the second year student of SMPN 3 Kabun.

The result his research, after he gave treatment the result of data analysis of post-test experimental class is 55.47 and standard deviation of experiment class is 3.42 . while, mean score of control class is 46.52 and standard deviation of control class is 2.41. it show that, mean score standard deviation of experiment class is greater than mean score and standard deviation of control class. Based on the result of this study, it could be concluded that the Repeated Reading Strategy could make the students active in learning and it also could develop reading fluency of the second grade students in SMPN 3 Kabun Rokan Hulu.

Therefore, in this research the researcher used the comprehension question to test the students' reading comprehension. To make easier for them to understand of the text, the researcher chose that strategy because the researcher was assumed that repeated reading strategy was the most appropriate strategy that could help their in reading comprehension.

\section{A. Definition reading comprehension}

Klinger (2007), state that reading comprehension is the process of conducting meaning by coordinating a number of complex processes that include word reading, world and world knowledge, and fluency.

According to Harris and Graham (2007:8) reading comprehension involves much more than readers' responses to the text. reading comprehension is a multicomponent, highly complex process that involves many interactions between readers and what they bring to the text (previous knowledge, strategy use) as well as variables related to the text itself 
(interest in text, understanding of the text types) .

Based on the definition of some experts above, it could be conclude that reading was not only the relationship between the text and reader's background knowledge, but also the relationship between author and the text and the reader got intended meaning from the text. Reading also provided a situation of the students to analyze what the writer purpose in the text.

\section{B. Reading Comprehension in Narrative text}

There are various kinds of text learned by students. One of them is narrative text. According to Nurzaida (2009) Narrative is mainly used to entertain in past tense. However, present tense can also be used within dialogues. Narrative text structure is usually the first structure that children are exposed to, and not surprisingly they are often more familiar with it than with order structures. Narrative is generally a sequence of events involving characters, actions, goals, and emotions. Skilled reader typically understands this series of event and expects the story to unfold in a certain way. This leads them to ask relevant questions about the story they are reading while they are reading it. Less skilled readers often lack mastery of this schema and must be taught how text is structured and what relevant question would be.

Narrative text has several kinds, They are :

1) Legend

A legend is a narrative of human actions that is perceived both by teller and listener to take place within human history. Typically, a legend is a short, traditional and historicized narrative perfomed in conversational mode. Some define legend as folktale. The examples of legend in narrative text are sangkuriang, malin kundang, the legend of tangkuban perahu and the story of Toba Lake.

2) Fable

A Fable is a short allegorical narrative making a moral point, traditionally by means of animal characters that speak and act like human being. The example of fable in narrative text are mousedeer and crocodile, the ants and the grasshopper, the smartes parrot and the story of monkey and crocodile.

3) Fairy tale

Fairy tale is an English language term for a type a short narrative corresponding to the French phrase "content de fee". A fairy tale typically features such folkloric characters as fares, goblins, elves, trolls, dwarves, giants, or gnomes. and usually magic or enchantments. 
The examples of fairy tale in narrative text are Cinderella, snow white, Pinocchio, beauty and the beast and the story of Rapunzel

4) Science fiction

Science fiction is a fiction based upon some imagined development of science, or upon the extrapolation of a tendency in society. Science fiction is that class of prose narrative treating of situations that could not arise in the world. Some examples of science fiction are to the moon from the earth by jules verne, starship trooper by Robert heinlen and space odyssey by Arthur c.clarke.

\section{Narrative text}

Narrative text is one of the types of text in reading that should be mastered by students especially for the second year students of junior high school. Whether it tells true story fiction, a narrative text an account of one or more experiences. This paragraph tells about a story to make a point or explains and idea or event that can be fun to read. The generis structure of narrative text is consist of three parts: orientation, complication, and resolution.

Syafi'i state that all narratives have certain elements in common, they are unfold overtime, have characters that display some type of emotion and center on events more than ideas. This statement emphasizes that narrative text is the text that built up by series of events that happened to characters in part time. According to this statement, the students can be called have ability in reading narrative that are the students should be able to find out main idea, characters, setting, recognize events, and cause and effect happened in narrative text. In other sides, the common grammatical features that used in narrative text they are:
a. Defined character
b. Descriptive language
c. Dialogue
d. Usually past tense

\section{Generic Structure Narrative text are as follows Peter and Megan (2005:222):}

1). Orientation

In this part, the writer tries to set up the people, time and place. Another way to construct the orientation part is trying to answer the questions that use who, what, where, when and so on.

\section{2). Complication}

The complication determined whether the text "lives" or not. If the narrative text considers the "live" text, it will arouse the reader. It intrudced to the emotion of reader. Commonly, narrative text appears story text. In literary term, the complication structure is called conflict. 
3). Resolution

In the resolution stage, the problem has to be solved and the text normally finishes a resolution to the problem simply, this stage is the end of the text.

\section{E. The Definition of Repeated Reading Strategy}

Repeated reading strategy is a strategy for supporting comprehension in a text. It is especially helpful when students need to read text containing of new information. According to samuels (1994). Repeated Reading is defined as " a supplemental reading program that consist of rereading a short and meaningful passage until a satisfactory level of fluency is reached. In line with to Huang (2009) The use repeated reading is an effective mechanism enabling students with reading challenges to complete favorably with students without the challenges

According to Swanson (2007), the Repeated Reading methodology assisted the students to decode appropriately at a normal rate. Ideally, the student can link graphemes and phonemes, hence acquiring significant comprehension skills. According to Compan (2001), Repeated Reading affects the behavior of students, especially their inner motivation to read alone. This means repeated reading enhances their fluency. The learning abilities seem to be a subset of the reading strengths of the learners.

\section{F. Procedure Repeated Reading Strategy}

Repeated reading is a strategy for supporting comprehension in a text. It is especially helpful when students need to read text containing of new information. According to Barbara Jet all (2009) state that definition of six patterns can be traced through the following explanation:

1. The teacher may select an interesting passage that is 50 to 100 words long from a book that is slightly above the student's independent reading level.

2. The teacher has the student read the selection orally while he or she times the reading and counts the number of words that are pronounced incorrectly.

3. The teacher then records the reading time and the number of words pronounced incorrectly. If desired, the teacher and student can set a realistic goal for speed and number of errors.

4. The teacher may use two different color pencils for recording time and errors, or a circle to indicate points on the line for time and an $\mathrm{X}$ or a square to indicate points on the line for errors. When the student is ready, he or she rereads the same passage. 
5. Once again, the teacher times the reading and recordsthe time and number of errors.

6. The student repeatedly practices reading the selection as the teacher charts progress after each trial until a predetermined goal is reached or until the student is able to read the passage fluently with few mistakes.

The strategy, the students assess their own interest in and prior knowledge of a topic before reading. After that, the students could be selected one reading text to be read. The students who can use this strategy were elementary, secondary and postsecondary students.

\section{METHOD}

This research used Experimental design. There were two classes as experiment class and control class. This research was experimental research. An experimental research is the traditional approach to conducting quantitative research (Creswell: 2012). The writer conducted the research in the difference classes experimental class and control class. In the experiment class the researcher gave a treatment by using Repeated Reading Strategy in teaching reading narrative text, while in the control class, the researcher taught reading narrative text by using small group discussion method without using
Repeated Reading Strategy. The treatment would be given in experimental class is purposed to compare whether it gave more significant effect on students' score in reading narrative text.

In the research, the researcher was applied of Repeated Reading Strategy to increase the students in reading comprehension ability of the students especially in narrative text to SMPN 36 Pekanbaru .To observed the activities of the researcher and the students during teaching and learning processes, the researcher needed a teacher-collaborator experimental of design. The researcher chose the English teacher of eight grade SMPN 36 Pekanbaru as teacher collaborator.

The researchers hope that by having the collaboration with the teacher - collaborator, the activities of the researcher and the students during learning process can be observed well.

\section{FINDING AND DISCUSSION}

This chapter shows the description of data analysis. There were two research questions that would be answered in this chapter. Firstly " to what extent can Repeated Reading strategy improve the students comprehension in reading narrative text at the grade VIII at SMPN 36 Pekanbaru ?" and secondly " what factors influence the changing of students' ability in reading 
comprehension reading narrative text at the grade VIII at SMPN 36 Pekanbaru ?" base on the questions would be answered the data obtained from the observation, pre-test- treatment, posttest and result

After analyzing both quantitative data, the researcher examined whether Repeated Reading strategy any effect the students' reading comprehension. The result below:

The Students' Reading Comprehension in the Test

\begin{tabular}{|c|c|c|}
\hline category & $\begin{array}{c}\text { Number of } \\
\text { students }\end{array}$ & percentage \\
\hline passed & 30 & $85,33 \%$ \\
\hline failed & 30 & $71,20 \%$ \\
\hline
\end{tabular}

The Students' Reading Comprehension Score in the Test

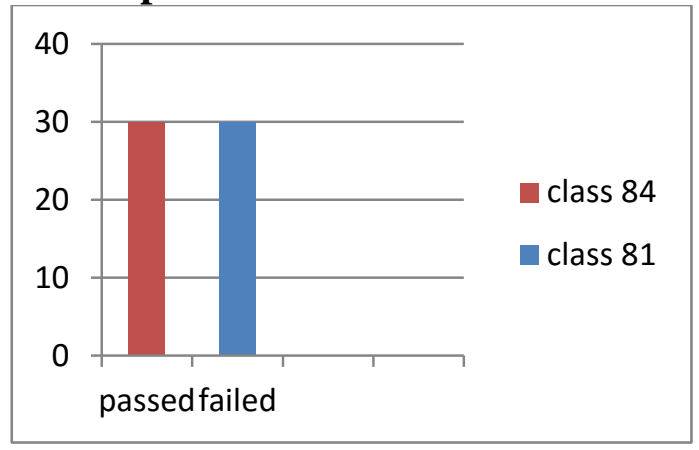

Based on the table and diagram above, there were 30 students class 81 who passed the passing grade criteria, and 30 were failed. The average score of the students' reading comprehension in narrative text was 85.33 .

\section{CONCLUSION}

After conducting this experimental of design at eighth grade students of SMP Negeri 36 Pekanbaru, and therefore based on the research findings, it can be concluded that :

Based on the test result, it was found that the average score of post-test was 85.33 and pre test was 71 . It means that the result of post test was getting higher than pretest. In conclusion, the use of repeated reading strategy could increase students reading comprehension in narrative text. There was different ability between experment and control class.

\section{REFERENCES}

Barbara J. Wending. 2009. Essentials of evidence-Based Academic Intervention. New Jersey: The Guilford Press.

Compan, B. 2001. Effect of Repeated Reading and Self Directed Behaviour on Reading Skills and Generalization of The Reading Skills of The Third- Grade Hill Tribe Students. Reports Research (143): 1-19

Cresswell, Jhon W. 2005. Educational Research.(Second Edition). New Jersey. Pearson Educational International. 
Harris, K. R and Graham, S. 2007. Teaching reading comprehension to students with learning difficulties. New York: The Guilford Publication.

Huang, Q. 2009. English Reading Based on Social Constructivist Approach. Asian Social Science ASS, 5 (7), 174-176.

Huang, Q. 2009. English Reading Based on Social Constructivist Approach. Asian Social Science ASS, 5 (7), 174-176.

M.Syafi,i. S. 2010. A Writing of English for Academic Purpose. Pekanbaru: Lembaga Bimbingan Syaf Intensif/LBSI

Patel and Praveen M. Jain. 2008. English Language Teaching "Methods, Tools, and Technique” Jaipur: Sunrise.

Patel and Praveen M. Jain. 2008. English Language Teaching "Methods, Tools, and Technique” Jaipur: Sunrise.

Samuels, S. J 1994. Theoritical models and processes of Reading. Newark, DE: International Reading Association

Siti. 2012. The Effect of Using Repeated Reading Strategy Toward Reading Fluency at the Second Year Students of SMPN 3 Kabun Rokan Hulu. Rokan Hulu
Swanson, HL. 2007. Repeated Reading Versus Continuous Reading: Influences on Reading Fluency and Comprehension. Exceptional Children: 74:31-46.

Vrieska, D., \& Kasriyati, D. (2017). Using Window Notes Strategy to Improving Students' Reading Skill in Narrative Text At Eight Grade of MTS Taufiq Walhidayah Pekanbaru. EltLectura, 4(2).

Wending, Barbara J. 2009. Essentials of Evidance-Based Academic Interventions New Jersey 